\title{
Recognition of factors that promote resilience to hurricanes
}

\author{
Adolfo Lucero Álvarez, Columba Rodríguez Alviso, \\ Oscar Frausto Martínez, José Luis Aparicio López, \\ Alejandro Díaz Garay, Maximino Reyes Umaña
}

\begin{abstract}
The economic damage and loss of lives caused by hurricanes have motivated efforts to expand scientific research related to resilience to these natural phenomena. However, published writings are dispersed and fragmented in different fields of study. This research is aimed to identify factors that promote resilience in hurricane-impacted areas by reviewing specialized literature. The study is qualitative, based on content analysis. Twenty-seven articles published between 2006 and 2019 were reviewed. The results show that resilience has a multidisciplinary character, although there is a coincidence in defining it as a system's ability to absorb, resist, and recover from disasters; the system is conceived as the representation of a totality made up of related elements (ecological, social, and economic, among others). A focus on physical infrastructure predominates, but a social approach begins to be distinguished. The factors that promote resilience are grouped into four categories: ecological, social, infrastructure, and mental health.
\end{abstract}

Keywords: disaster, hurricanes, recovery, resilience, resistance, risk, socio-ecological system

Because of the concern to avoid loss of human lives and reduce economic damage caused by the increase and variability of disasters due to climate change, the document Transforming Our World: the 2030 Agenda for Sustainable Development (United Nations, 2015) considers actions to strengthen resilience through the construction of resistant infrastructures and make cities and human settlements inclusive, safe, resilient, and sustainable. In tune, to decrease damage and increase resilience to disturbances caused by disasters, the United Nations created the Sendai Framework for Disaster Risk Reduction 2015-2030 with four action priorities and seven global goals. 
Today, hurricanes cause enormous damage to people, especially those who settle in coastal areas. Prevention measures against the effects of these phenomena are insufficient due to changes in intensity and frequency and their varying development, so there is a need for studies focused on unveiling actions to increase the resilience of the population to hurricanes.

Holt (2006) underpins that damage related to hurricanes are unpredictable and inevitable and cause different degrees of loss and damage; their spatial manifestation varies from a locality to large-scale massive catastrophes (Holt, 2006). These phenomena can cause millions of dollars in losses by destroying homes, damaging public transport infrastructure and hospitals, and limiting access to the resources necessary to survive, such as water, food, and health (Gruebner et al., 2015). Damage can be severe and seriously affect residents in impact areas (Pietrzak et al., 2012; Wang and Taylor, 2014). Despite increasing awareness of its effects, Gruebner et al. (2015) point out that it is impossible to determine and address all vulnerabilities and protect individuals, communities, and society.

After a disaster, the recovery will depend on the preparedness, mitigation, and responsiveness of stakeholders (Tokgoz \& Gheorghe, 2013). To increase system resilience, planners should understand and incorporate into their assessments and planning processes, the perception and concerns of stakeholders (Becker et al., 2015), and the awareness and behavior of society (Leroy et al., 2016).

Resilience is considered a useful tool in designing strategies to reduce the damage caused by disasters. Although the literature on the topic is abundant, there are few studies focused on identifying factors that promote the system's resilience against damage caused by hurricane impacts. Furthermore, they are specialized studies that do not offer an overview of the phenomenon. There has been little research on the characteristics of hurricanes, the damage they cause, and the strategies and actions that can contribute to strengthening resilience in socio-ecological environments at risk; additionally, there is a lack of scientific evidence to understand the complexity of the phenomenon and the diversity of environmental, social, and economic impacts.

It is pertinent to carry out a review study to merge and evaluate up-todate literature and to know the most widespread trends and ideas in the world, it may contribute to the awareness and strengthening of resilience in coastal areas affected by hurricanes. To achieve this goal, two research questions have been posed: (1) What are the most common definitions of resilience used in hurricane studies? and (2) How are the factors that contribute to strengthening resilience to hurricanes classified? 


\section{Research design and methodology}

A qualitative methodological design based on content analysis of specialized journals on resilience with an emphasis on three aspects was followed: frequency of keywords in the summaries, definitions of resilience, and factors that promote it. The process was divided into two phases: (1) collection and organization of data; and (2) coding and categorization.

\section{Collection and organization of data}

The Science Direct and Scopus databases were used as search engines. The former is multidisciplinary and allowed consulting the production in scientific journals published by Elsevier Publishing House, while the latter allowed access to articles produced by different international publishers. The search was based on all open access articles published until 2019.

In Science Direct, the criterion "advanced search" was used; later, in the "find articles with these terms" section, the words "hurricane" and "resilience" were introduced. Search terms were limited to being contained in the title of the publication. Fourteen articles were found under these criteria in resilience to hurricanes field study. In the Scopus database, the articles taken into account were open access and included the terms "hurricane" and "resilience." Thirteen documents coincided with these characteristics. In total, 27 articles were found in both databases (Table 1).

Table 1 List of 27 articles on resilience to hurricanes

\begin{tabular}{llll}
\hline Title & Autor & Year & Engine \\
\hline $\begin{array}{l}\text { 1. Resilience after Hurricane Katrina among pregnant } \\
\text { and postpartum women }\end{array}$ & Harville et al. & $2010 \begin{array}{l}\text { Science } \\
\text { Direct }\end{array}$ \\
$\begin{array}{l}\text { 2. Investigating the role of impoundment and } \\
\text { forest structure on the resistance and resilience } \\
\text { of mangrove forests to hurricanes }\end{array}$ & Vogt et al. & 2012 & $\begin{array}{l}\text { Science } \\
\text { Direct }\end{array}$ \\
$\begin{array}{l}\text { 3. Multi-dimensional hurricane resilience assessment } \\
\text { of electric power systems }\end{array}$ & $\begin{array}{l}\text { Ouyang \& } \\
\text { Dueñas-Osorio }\end{array}$ & 2014 & $\begin{array}{l}\text { Science } \\
\text { Direct }\end{array}$ \\
$\begin{array}{l}\text { 4. From vulnerability to resilience: An exploration } \\
\text { of gender performance art and how it has enabled } \\
\text { young women's empowerment in post-hurricane } \\
\text { New Orleans }\end{array}$ & $\begin{array}{l}\text { Overton, } \\
\text { L. R-A. }\end{array}$ & 2014 Science \\
$\begin{array}{l}\text { 5. Towards seaport resilience for climate change } \\
\text { adaptation: Stakeholder perceptions of hurricane } \\
\text { impacts in Gulfport (MS) and Providence (RI) }\end{array}$ & Becker et al. & 2015 & $\begin{array}{l}\text { Science } \\
\text { Direct }\end{array}$ \\
& & &
\end{tabular}




\begin{tabular}{l} 
Title \\
\hline 6. Reflecting on resilience in Broward County, Florida: \\
A newspaper content analysis about Hurricane \\
Wilma recovery \\
7. Enhanced resilience and resistance assessment with \\
virtual ecoenergy for a subtropical lake ecosystem \\
under the intermittent impact of hurricanes and \\
droughts \\
8. Resilience of soil nutrient availability and organic \\
matter decomposition to hurricane impact in a \\
tropical dry forest ecosystem \\
9. Resilience of tropical dry forest productivity to two \\
hurricanes of different intensity in western Mexico \\
10. Habitat heterogeneity facilitates resilience of diurnal \\
raptor communities to hurricane disturbance
\end{tabular}

11. Understanding hurricane resistance and resilience in tropical dry forest trees: A functional traits approach

12. Pre-hurricane optimal placement model of repair teams to improve distribution network resilience

13. Resilience improvement planning of power-water distribution systems with multiple microgrids against hurricanes using clean strategies

14. Power distribution system improvement planning under hurricanes based on a new resilience index

15. Making a virtue out of a necessity: Hurricanes and the resilience of community organization

16. Short-term hurricane impacts on a neotropical community of marked birds and implications for early stage community resilience

17. Resilience in the face of disaster: Prevalence and longitudinal course of mental disorders following Hurricane Ike

18. Resilience quantification and its application to a residential building subject to Hurricane Winds

19. Quantifying human mobility perturbation and resilience in Hurricane Sandy

20. The geography of post-disaster mental health: Spatial patterning of psychological vulnerability and resilience factors in New York City after Hurricane Sandy

21. A linear relationship between wave power and erosion determines salt-marsh resilience to violent storms and hurricanes

\begin{tabular}{lll} 
Autor & Year & Engine \\
\hline Torres \& & 2016 & Science \\
Alsharif & & Direct
\end{tabular}

Chang \& Wen 2017 Science Direct

Gavito et al. $2018 \begin{aligned} & \text { Science } \\ & \text { Direct }\end{aligned}$

Martínez-Yrízar 2018 Science et al. Direct

Martínez-Ruiz 2018 Science \& Renton Direct

Paz et al. 2018 Science Direct

\begin{tabular}{|c|c|c|}
\hline $\begin{array}{l}\text { Khomami \& } \\
\text { Sepasian }\end{array}$ & 2018 & $\begin{array}{l}\text { Science } \\
\text { Direct }\end{array}$ \\
\hline Najafi et al. & 2019 & $\begin{array}{l}\text { Science } \\
\text { Direct }\end{array}$ \\
\hline Najafi et al. & 2018 & $\begin{array}{l}\text { Science } \\
\text { Direct }\end{array}$ \\
\hline Holt, R. D. & 2006 & Scopus \\
\hline $\begin{array}{l}\text { Johnson \& } \\
\text { Winker }\end{array}$ & 2010 & Scopus \\
\hline
\end{tabular}

Pietrzak et al. 2012 Scopus

Tokgoz \& 2013 Scopus

Gheorghe

Wang \& Taylor 2014 Scopus

Gruebner et al. 2015 Scopus

Leonardi et al. 2016 Scopus (continued) 


\begin{tabular}{|c|c|c|c|}
\hline Title & Autor & Year & Engine \\
\hline $\begin{array}{l}\text { 22. Psychological resilience after Hurricane Sandy: The } \\
\text { influence of individual- and community-level factors } \\
\text { on mental health after a large-scale natural disaster }\end{array}$ & Lowe et al. & 2015 & Scopus \\
\hline $\begin{array}{l}\text { 23. Building network-level resilience to resource } \\
\text { disruption from flooding: Case studies from the } \\
\text { Shetland Islands and Hurricane Sandy }\end{array}$ & $\begin{array}{l}\text { Brown \& } \\
\text { Dawson }\end{array}$ & 2016 & Scopus \\
\hline $\begin{array}{l}\text { 24. Hurricane resilience indicators in Mexican } \\
\text { Caribbean coastal cities }\end{array}$ & Frausto et al. & 2016 & Scopus \\
\hline $\begin{array}{l}\text { 25. Vulnerability and social resilience: Comparison } \\
\text { of two neighborhoods in New Orleans after } \\
\text { Hurricane Katrina }\end{array}$ & Leroy et al. & 2016 & Scopus \\
\hline $\begin{array}{l}\text { 26. Optimal hurricane overwash thickness for } \\
\text { maximizing marsh resilience to sea level rise }\end{array}$ & $\begin{array}{l}\text { Walters \& } \\
\text { Kirwan }\end{array}$ & 2016 & Scopus \\
\hline $\begin{array}{l}\text { 27. Spatial and temporal variations in resilience to } \\
\text { tropical cyclones along the United States coastline } \\
\text { as determined by the multi-hazard hurricane } \\
\text { impact level model }\end{array}$ & $\begin{array}{l}\text { Pilkington \& } \\
\text { Mahmoud }\end{array}$ & 2017 & Scopus \\
\hline
\end{tabular}

Source: Science Direct and Scopus databases

\section{Coding and categorization}

Table 2 was designed to record information on each item. The data were stored in a hermeneutic unit of Atlas.ti program, where an identification number for each item was assigned, as well as a code for 15 sections. On this basis, to have an overview of the articles, four sections were created:

(1) Information about publications to identify the title, year, journal name, keywords, and the number of citations.

(2) Research context to obtain information from the object of study, hurricane type, knowledge area (or discipline), region, and country.

(3) Referential framework to know resilience definitions, and to identify and classify factors that promote it by field of knowledge.

(4) Final considerations and conclusions.

The word cloud technique allowed to know the most frequently used words in definitions of resilience and the summaries of all articles. Descriptive statistics were used to show the results of the review in frequencies and percentages.

The content analysis led to a classification of the data collected; they were organized by classes, which were named "factors that promote resilience"; each factor was subdivided into sets named "categories" and "subcategories." This classification was submitted to the judgment and validation of this group of researchers. 
Table 2 - Literature review on resilience to hurricanes, 2006-2019

\begin{tabular}{ll}
\hline Sections & Subsections \\
\hline Publication information & Author \\
& Year of publication \\
& Article title \\
& Magazine name \\
& Keywords \\
& Quotations number \\
& Study object \\
& Type of disaster (hurricane) \\
Research context & Knowledge area \\
& Study zone \\
& Country \\
& Definition \\
Referential framework & Factors that promote resilience \\
& Final considerations \\
Results and conclusions & Conclusions \\
&
\end{tabular}

Source: Authors

\section{Literature review}

Global warming and climate change have caused natural disasters that occurred with great intensity in recent decades (Khomami \& Sepasian, 2018). These phenomena can never be stopped, but it is possible to work on reducing their impact. This is why disaster planners must learn what characterizes resilient people, to encourage them to be prepared with a resistance system to ensure the rapid recovery in disaster areas (Harville et al., 2010; Ouyang \& Dueñas-Osorio, 2014).

Actions to respond to shocks should carefully consider and evaluate how short-term benefits can affect long-term goals (Torres \& Alsharif, 2016). Resilience seeks to obtain a better and safer state; the faster a system returns to a balanced state after an event, the more resistant it becomes (Leroy et al., 2016). After the occurrence of a natural disaster, the most important task of the system is the recovery in the shortest possible time (Khomami \& Sepasian, 2018).

Traditional approaches to resilience are focused on risk management and threat control; they show a materialistic vision based on the logic of increasing the resistance of physical protection structures to avoid danger. However, these models have shown limitations and insufficiency in the face of intensifying disruptive events (Quenault, 2013; Reghezza-Zitt, 2013). Technical protection measures are not fully reliable, as demon- 
strated in recent disasters, like the one caused by Hurricane Katrina in 2005 (Leroy et al., 2016).

Specific topics focused on infrastructure, ecology, mental health, and sociology prevail in the literature on resilience to hurricane disasters. According to Khomami and Sepasian (2018), increasing resilience has become a priority due to the extreme dependence on other critical services, and Tokgoz and Gheorghe (2013) point out that after a disaster, infrastructure and buildings should return to normal operations as quickly as possible to minimize negative effects and incorporate resilience strategies before (preparation and mitigation) and after the event (response and recovery).

From sociology, patterns of social mobility in coastal areas could be examined with a hurricane approach to obtain a more effective evaluation and develop strategies and policies to reduce mortality, injuries, and economic loss (Wang \& Taylor, 2014). To ensure community resilience, it is important to maintain the flow of food, materials, fuel, water, and other vital resources before, during, and after a flood (Brown \& Dawson, 2016). Social resilience is about raising awareness of risk and improving the possibility to face the event rationally (Leroy et al., 2016). The literature on disaster mental health provides studies on mental disorders in individuals after a disaster, such as post-traumatic social disorders, general anxiety disorder, panic disorder depression, and suicidal tendencies (Pietrzak et al., 2012).

The issue of hurricane resilience has not been extensively examined (Harville et al., 2010). To provide useful elements for decision-making, an analysis of current and specialized literature was conducted, seeking to recognize factors that promote resilience to hurricanes of impacted areas before, during, and after the phenomenon. Until the completion of this study, there was no record of another proposal aimed to analyze these worrisome issues.

\section{Conceptual approach}

The concept of resilience has gained attention in disaster management, especially after the man-made disaster of the September 11, 2001 attacks and the 2005 natural disaster of Hurricane Katrina (Leroy et al., 2016; Tokgoz \& Gheorghe, 2013). The concept of resilience has progressively gained momentum, the success of a system relies more and more on its capacity to react to sudden shocks in a positive and evolutionary perspective (Rota et al., 2020).

Today, resilience is the conceptual framework for disaster risk management; it is defined as the joint capacity of a system to resist (prevent and bear) multiple possible risks, absorb initial damage, and recover to 
normal operation (Ouyang \& Dueñas-Osorio, 2014); it takes into account how the system reacts by itself through self-organization and how it will react in the future, depending on how it adapts and finds a more sustainable balanced state (Leroy et al., 2016). Although definitions of resilience vary, some scholars distinguish between two scales: specified resilience, addressing resistance to known shocks, and general resilience, addressing the ability of a system to cope with less predictable shocks (Torres \& Alsharif, 2016).

Resilience links abilities of resistance, recovery, and transformation, with economic, social, infrastructure, and ecological aspects. The studies of Brigite Maguire and Patrick Hagan (2007) focused on the maximum pressure that the system can withstand without changing its function and structure; this includes three abilities: resistance, recovery, and creativity. Resistance relates to the efforts of a system to withstand a disaster and its consequences; recovery describes the function by which a system can return, after a certain period, to the previous state, the faster it takes place, the more resilient it becomes; and creativity is considered the ability of a system to adapt to the new situation, so the system is not only restored to its original level but reaches a higher one. This means that resilience is not related to the ability to return to a system's initial state but to get back to a balanced state, a better one whenever possible, even if it differs from the original one (Leroy et al., 2016). Taquechel and Lewis (2017) point out that resilience must go beyond the ability to return to a normal predisturbance state, adding that the system must benefit from disorder instead of suffering. It must evolve and exceed levels of performance prior to the alteration until finding a new balance, that is, reducing the fragility and increasing the antifragility of the system. The goal of antifragility is to benefit, thrive, and become even stronger after disturbance. In this sense, Alexander (2006) argues that systems would be more effective if they would place much greater emphasis on foreseeing and preparing for impacts rather than simply reacting to them.

An antifragile agent always maintains or improves its condition in the face of highly unlikely and unpredictable undesirable events, making sure to have all options covered if what will happen is not known (Fuller, 2013). While resilient systems are simply tough and remain unchanged, antifragile structures not only withstand stress but also benefit from it (Rota et al., 2020). Antifragility is a property that improves the responsiveness of the system when exposed to external disturbances, benefits from stress, strengthens, and prepares to overcome future adversities (Pineda et al., 2019).

To contribute with proposals to bring this concept from theory to practice, Susan L. Cutter et al. (2008) establish five components of resil- 
ience: (1) the social component links demographic attributes to social capacity; (2) the economic part, refers to a diversification of local economic base as a factor that strengthens resilience; (3) the institutional element, contains characteristics related to mitigation, planning and previous experience before the disaster; (4) infrastructure, refers to community response and resilience (shelter, availability of rental housing, health facilities, and housing infrastructure that may be vulnerable to damage and possible economic losses); and (5) the community component, highlights the relationships between individuals, neighborhoods, and communities. Identifying factors that promote resilience is crucial in disaster rapid recovery of hurricane-affected areas. This is why the system must not only be restored to its normal state and function but also be transformed to emerge stronger and better prepared to face future disasters.

\section{Results}

\section{Publications information}

Studies of resilience to hurricanes disasters are relatively recent. Of the 27 articles reviewed, 24 corresponded to the period of 2012-2019; out of them, 15 were issued between 2016 and 2019. The foregoing reflects the growing interest in researching on the exposed subject. The most cited article is about an analysis of the resilience of electric power systems to hurricanes (Ouyang \& Dueñas-Osorio, 2014); the second with most citations is a study of mental health linked to traumatic events (Pietrzak et al., 2012); and in third place, the work of Sarah R. Lowe et al. (2015) discusses the influence of factors at the individual and collective levels to shape post-disaster psychological resilience. Table 3 shows the most cited articles.

\section{Research context}

To know the conditions and realities in which the analyzed studies were carried out, five aspects were considered: object of study, hurricane name, knowledge area, study area, and country. From the total number of articles reviewed, nine (33\%) were aimed at the resilience of an ecosystem (mangroves, lakes, soil nutrients, forests, marshes, raptors habitat, birds, and spiders communities); six (22\%) were aimed at infrastructure (electrical power system, restoration of the electrical distribution system, micro-networks of energy and water, distribution networks of the energy system, residential buildings, and infrastructure and supply chains); 


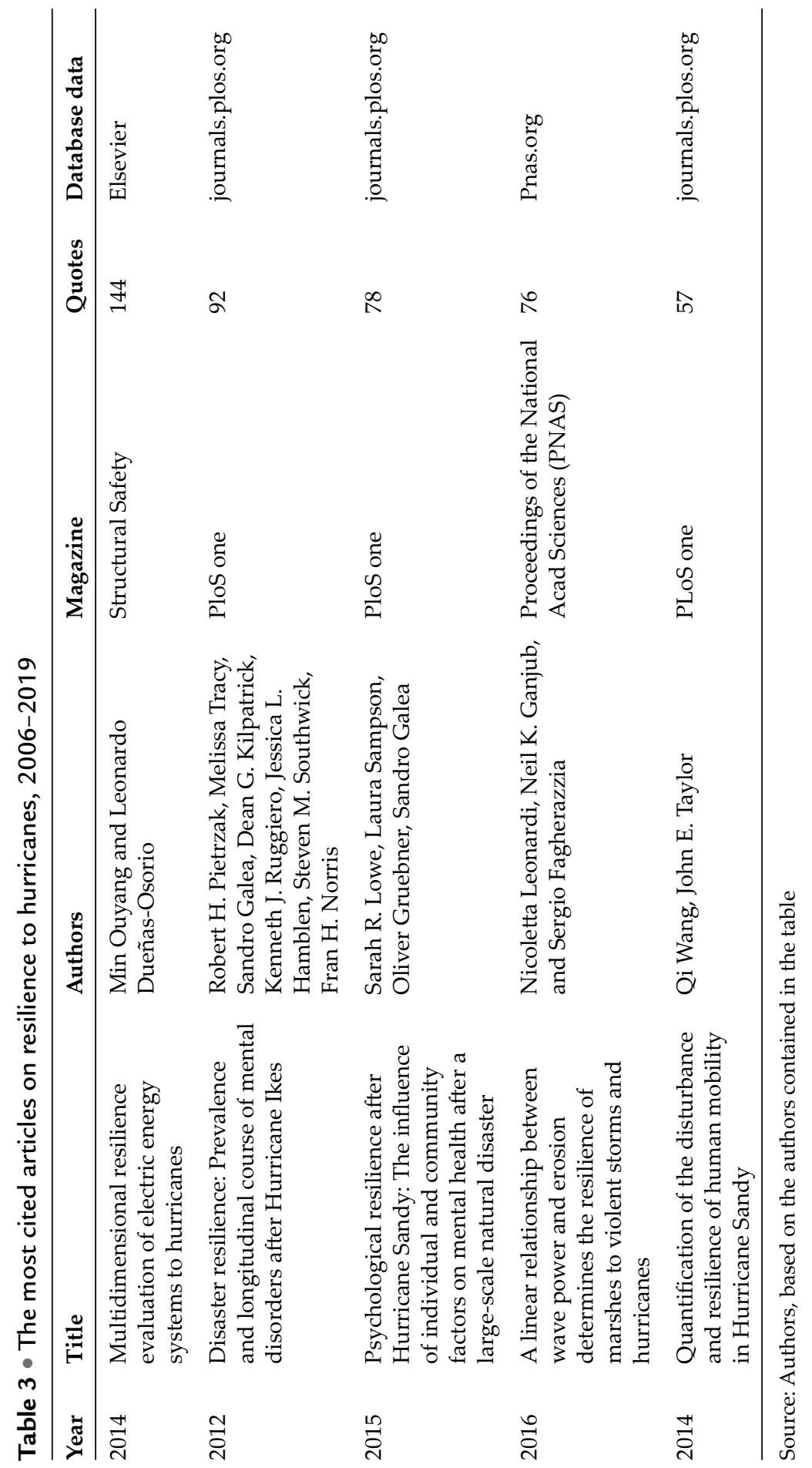


seven $(26 \%)$ were aimed at community resilience (seaport, human mobility, distribution of population's mental health, lesbian community, gay, bisexual, transgender, and queer community); three (11\%) were aimed at individual resilience (mental health, psychiatric and psychological disorders); one (4\%) was aimed at urban resilience; and one (4\%) was aimed at economic resilience.

Regarding the hurricanes studied, Table 4 shows that, of all the articles reviewed, four examined Hurricane Sandy, which impacted the eastern part of the United States in 2012. Four others studied the effects of Hurricanes Jova and Patricia of 2012, in the Chamela-Cuixmala Biosphere Reserve and in the communities of La Huerta and Tomatlán, in Jalisco State, Mexico. Three studies dealt with Hurricane Katrina that hit New

Table 4 - The most studied hurricanes

\begin{tabular}{|c|c|c|c|c|c|c|}
\hline Hurricane & Year & Study area & State/Region & Country & Frequency & $\%$ \\
\hline Katrina & 2005 & $\begin{array}{l}\text { New Orleans and } \\
\text { Baton Rouge } \\
\text { New Orleans (2) }\end{array}$ & $\begin{array}{l}\text { Louisiana } \\
\text { Louisiana }\end{array}$ & USA & 03 & 11.1 \\
\hline Sandy & 2012 & $\begin{array}{l}\text { New York City ( } 3 \text { ) } \\
\text { Shetland Islands and } \\
\text { New York City }\end{array}$ & $\begin{array}{l}\text { NY } \\
\text { UK-New York }\end{array}$ & $\begin{array}{l}\text { USA } \\
\text { UK-USA }\end{array}$ & 04 & 14.8 \\
\hline $\begin{array}{l}\text { Jova and } \\
\text { Patricia }\end{array}$ & 2011 & $\begin{array}{l}\text { Chamela Biosphere } \\
\text { Reserve-Cuixmala (3) } \\
\text { La Huerta and } \\
\text { Tomatlán }\end{array}$ & $\begin{array}{l}\text { Jalisco } \\
\text { Jalisco }\end{array}$ & $\begin{array}{l}\text { MEX } \\
\text { MEX }\end{array}$ & 04 & 14.8 \\
\hline Ike & 2008 & $\begin{array}{l}\text { Harris County } \\
\text { Galveston and } \\
\text { Chambers Counties }\end{array}$ & $\begin{array}{l}\text { Texas } \\
\text { Texas }\end{array}$ & USA USA & 02 & 7.4 \\
\hline Wilma & 2005 & Broward County & Florida & USA & 01 & 3.7 \\
\hline $\begin{array}{l}\text { Francesy } \\
\text { Jeanne }\end{array}$ & 2004 & Indian River Lagoon & Florida & USA & 01 & 3.7 \\
\hline Floyd & 1998 & Bahamas Islands & Baham Islands & BI & 01 & 3.7 \\
\hline Iris & 2001 & South Toledo District & Belize & Belize & 01 & 3.7 \\
\hline $\mathrm{N} / \mathrm{S}^{*}$ & $\mathrm{~N} / \mathrm{S}$ & $\begin{array}{l}\text { Gulfport / Providence } \\
\text { Lake Okeechobee } \\
\text { South Florida } \\
\text { Hog island } \\
\text { East Coast and Gulf } \\
\text { Playa del Carmen, } \\
\text { Tulum and Chetumal } \\
\text { Four: N/S }\end{array}$ & $\begin{array}{l}\text { Mississippi/ } \\
\text { Rhode Island } \\
\text { Florida } \\
\text { Florida } \\
\text { Virginia } \\
\text { East Coast/Gulf } \\
\text { Quintana Roo } \\
\text { N/S }\end{array}$ & $\begin{array}{l}\text { USA } \\
\text { USA } \\
\text { USA } \\
\text { USA } \\
\text { USA } \\
\text { MEX } \\
\text { N/S }\end{array}$ & 10 & 37 \\
\hline
\end{tabular}

${ }^{*}$ Not Specified 

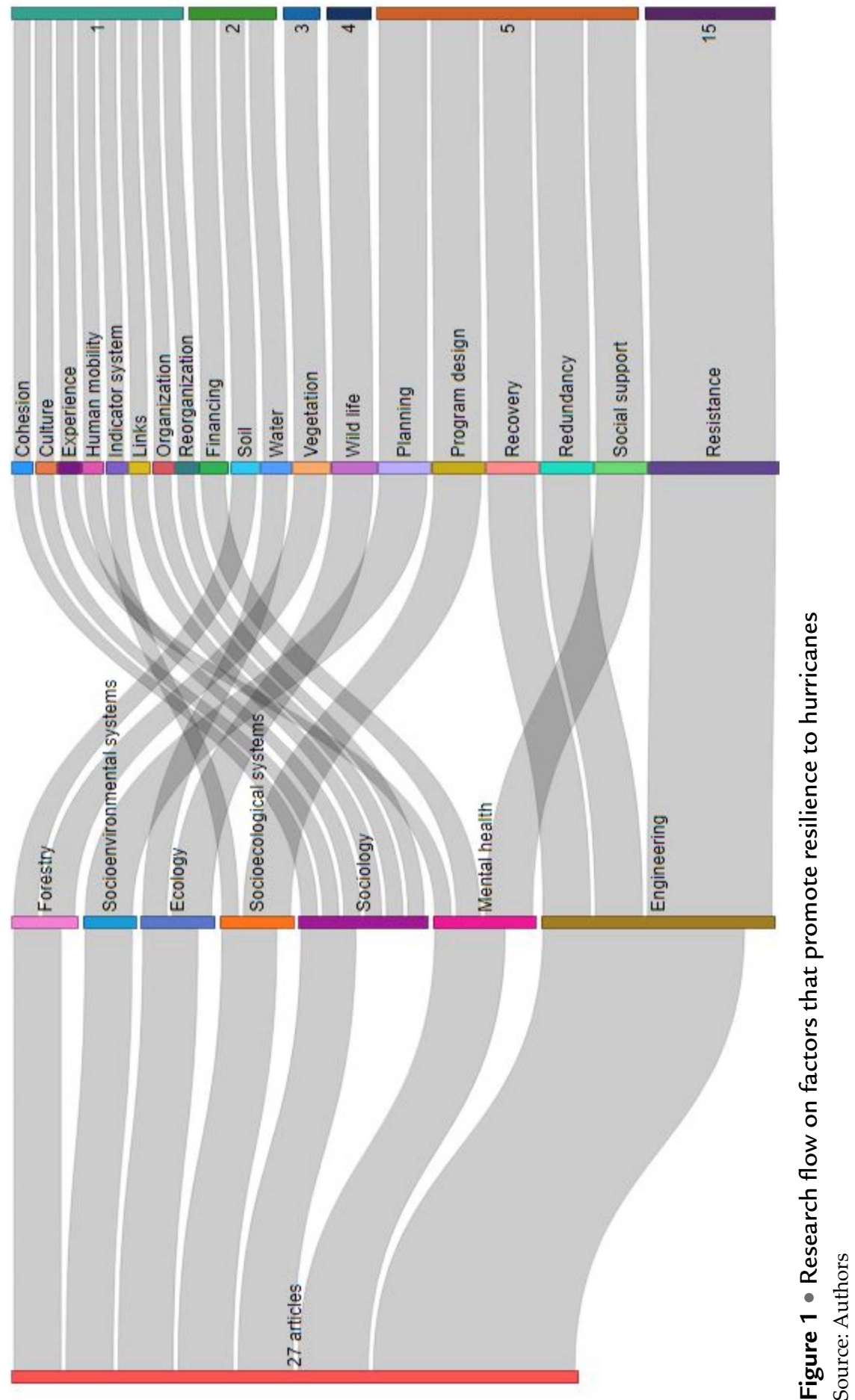
Orleans, Louisiana, on the US East Coast in 2005. Two more studies correspond to Hurricane Ike of 2008, in Galveston and Chambers counties, in Texas. One article studied hurricanes France and Jeanne of 2004 in Indian River Lagoon, Florida. Another article examined hurricane Iris of 2001 in Southern Toledo District, Belize. Of the remaining ten articles that do not mention the hurricane studied, five were carried out in the United States, one in Mexico, and four did not specify name of hurricane, year, study area, state, or country.

The 27 articles found were distributed in different areas of knowledge and theoretical approaches: ecology (7), engineering (7), forestry (3), mental health (3), sociology (3), socio-ecological systems (2), psychology (1), and socioenvironmental systems (1) (Figure 1). By field of study, $34 \%$ of the articles were made on a regional scale; $19 \%$ in cities; $7 \%$ in counties, $7 \%$ in districts, $7 \%$ on islands, $7 \%$ in places occupied by small communities and some social groups, $4 \%$ at country level, $4 \%$ at lagoons, $4 \%$ in localities, and $7 \%$ not specified. By country, $55 \%$ of the articles correspond to research carried out in the United States, $18 \%$ in Mexico, $4 \%$ in the Bahamas, $4 \%$ in Belize, $4 \%$ in the United Kingdom and United States, and $15 \%$ did not specify.

\section{What is resilience?}

As a multidisciplinary concept, there is no consensus on resilience. Study fields and theoretical approaches have different emphases; their use has traditionally been addressed to the evaluation of natural hazards (Frausto et al., 2016). And programs in hazard mitigation tend to focus more on increasing the system's physical resistance to cope with disasters than on social resilience.

Different fields of knowledge have adopted a wide variety of terms; in this literature review alone, 126 different words were found in nine definitions. Coincidences were also found: all the definitions referred to the capacity or ability of the system; subsequently, terms such as absorb, resist, or recover were used (Table 5).

The most cited article defined resilience as the ability to prevent and resist multiple possible hazards, absorb initial damage, and recover to normal function (Ouyang \& Dueñas-Osorio, 2014). Brian Walker et al. (2006, cited by Becker et al., 2015), authors of the second most cited article, refer to resilience as the ability of a system to absorb disturbances and preserve its basic function and structure. The third most cited article, the "International Panel on Climate Change" (2014, cited by Torres \& Alsharif, 2016) explains it as the capacity of social, economic, and environmental 
Table 5 - Definition of resilience of the most cited articles

\begin{tabular}{|c|c|c|c|}
\hline Article & Author & Cited definition & Cited author \\
\hline $\begin{array}{l}\text { Multidimensional } \\
\text { assessment of the } \\
\text { resilience of electric } \\
\text { power systems to } \\
\text { hurricanes }\end{array}$ & $\begin{array}{l}\text { Ouyang and } \\
\text { Dueñas-Osorio, } \\
2014 . \\
144 \text { quotes }\end{array}$ & $\begin{array}{l}\text { Resilience is the capacity for } \\
\text { joint recovery of distributed } \\
\text { systems such as electric } \\
\text { power systems, to resist } \\
\text { (prevent and support) } \\
\text { multiple potential risks, } \\
\text { absorb the initial damage } \\
\text { and recover their normal } \\
\text { operation. }\end{array}$ & $\begin{array}{l}\text { Ouyang y } \\
\text { Dueñas-Osorio, } \\
2012\end{array}$ \\
\hline
\end{tabular}

Towards port resilience for climate change adaptation: Stakeholder perceptions of hurricane impacts in Gulfport (MS) and Providencia (RI)

Reflecting on the resilience County Broward, Florida: content analysis of a newspaper about the recovery of Hurricane Wilma

Resilience nutrient availability and soil decomposition of organic matter 1 impact of hurricanes in a forest ecosystem tropical dry
Becker et al., Resilience is the ability $2015 . \quad$ of a system to absorb 45 quotes disturbances and still retain its basic function and structure.

Torres and Resilience is the ability of Alsharif, 2016. structure, while maintain10 quotes

ing social, economic, and environmental systems to cope with a dangerous event, trend, or disruption, responding or reorganizing in ways that maintain their essential function, identity, and adaptive, learning capacity and transformation.

Gavito et al., Resiliency is the ability of 2018. 03 quotes a system to maintain its function when it is exposed to disturbances, has two measurable components, the resistance (ability to withstand shocks without changing) and the recovery (ability to return to conditions predisturbio when the system does not resisted). Both components together represent resilience.
Walker, Salt and Reid, 2006.

Quoted by Becker, et al., 2015

IPCC, 2014.

Quoted by

Torres and

Alsharif, 2016
Hodgson et al. 2015, cited by Gavito et al., 2018

Source: Authors, based on the authors contained in the table

systems to face a dangerous event, trend, or disturbance, by responding or reorganizing in a way that they can maintain their essential function, identity, and structure while retaining the ability to adapt, learn, and transform. Therefore, they show similarity in the approach to resilience as a system to resist, absorb, and recover its essential functions and structure. It should be noted that Mayra E. Gavito et al. (2018) highlight resistance 
and recovery capabilities as properties of resilience: resistance as the ability to remain unchanged, and recovery as the ability to return to normal conditions.

Figure 2 shows the most used terms in resilience definitions. The frequency allows them to be ordered as follows: first, those related to resilience; later those referred to the capacity or ability of the system, in a first phase of resisting, supporting, and maintaining; and in the end, those that correspond to the recovery phase, when the system did not resist and returned to the normal or original conditions and functions that the system had before the disturbance.

In the summaries of a second analysis on word frequency, terms like hurricanes, resilience, and disasters were positioned as the central themes. Based on the this, hurricane resilience could be defined as the system's capacity for resistance, recovery, and transformation to emerge stronger against future disasters.

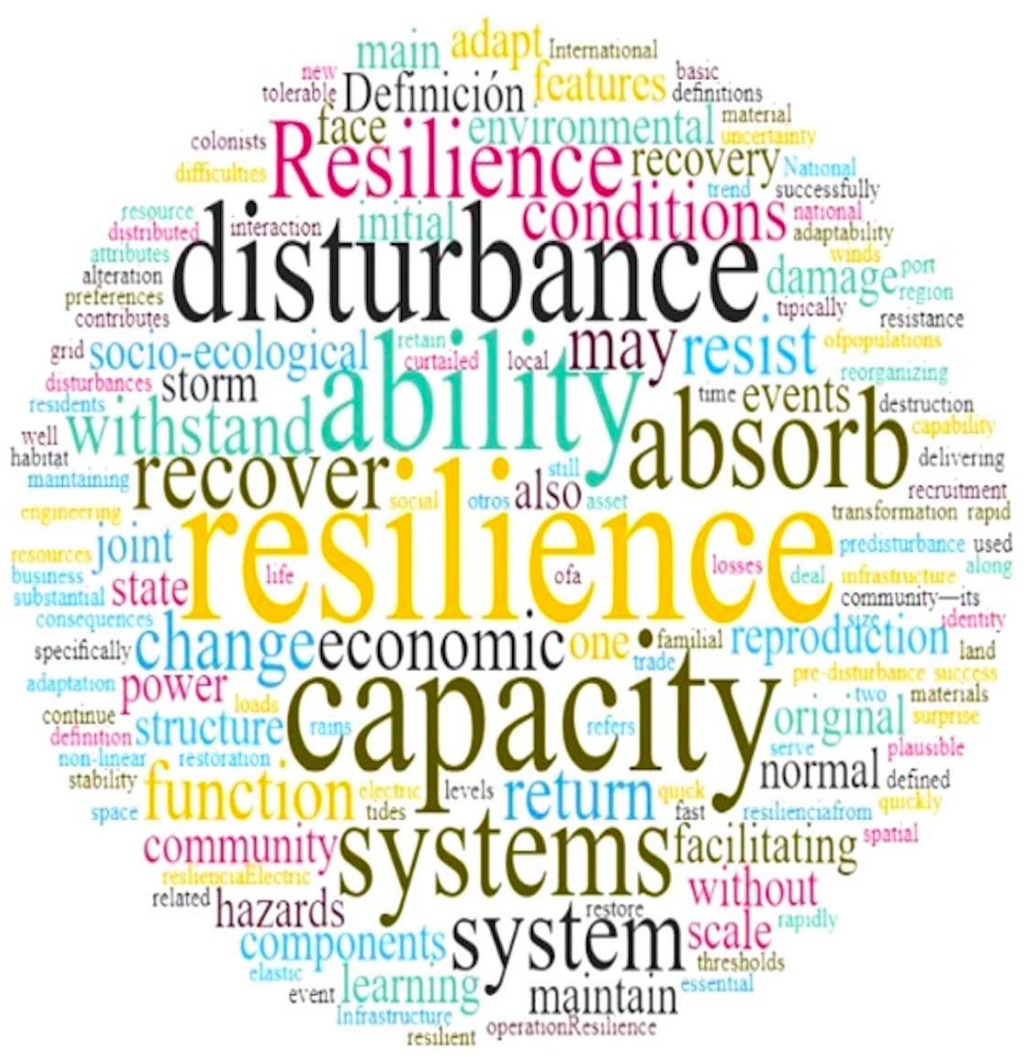

Figure 2 - Word cloud found in resilience definitions of reviewed articles 


\section{Factors that promote resilience to hurricanes}

From the diversity of proposals and theoretical approaches that have studied resilience to hurricanes, it was possible to classify them into four groups: ecological, social, infrastructure, and mental health. Consequently, 19 categories and 61 subcategories were obtained.

\section{Ecological}

Vegetation, wildlife, water availability, and soil have been identified as the categories in which factors favoring resilience can be grouped (Table 6). In this fashion, an important relationship was found between water availability and soil nutrients for forest regeneration, which provides alternative habitats for wildlife recovery and, in general, for the entire ecosystem's resilience.

\section{Vegetation}

Characteristics that promote vegetation resilience are related to tree diversity and heterogeneity (Gavito et al., 2018). Also, native mangroves vegetation and smaller trees have shown greater resistance and speed recovery to hurricanes (Vogt et al., 2012). On the other hand, contrary to the notion that dense trees in dry tropical forests should better resist to

Table 6 - Ecological factors that promote resilience in hurricane-affected areas

\begin{tabular}{lll}
\hline Category & Subcategory & Author \\
\hline \multirow{2}{*}{ Vegetation } & Diversity/heterogeinety & Gavito et al. (2018) \\
\cline { 2 - 3 } & Native vegetation & Vogt et al (2012) \\
\cline { 2 - 3 } & Tree structure & Paz et al. (2018) \\
\hline \multirow{2}{*}{ Wildlife } & Mobility & Martínez-Ruíz and Renton (2018) \\
\cline { 2 - 3 } & Alternative habitats & \\
\hline \multirow{2}{*}{ Water } & Migration & Johnson and Winker (2010) \\
\hline \multirow{2}{*}{ Soil } & Water availability & Martínez-Yrizaret al. (2018) \\
\cline { 2 - 3 } & Artificial floods & Vogt et al. (2012) \\
\hline
\end{tabular}

Source: Authors, based on the authors contained in the table 
hurricanes, such weather events may favor trees with reduced canopies, ductile wood, flexible leaves, and wide-stemmed logs, and rapid growth, because they are less susceptible to damage and tend to sprout vigorously (Paz et al., 2018).

\section{Wildlife}

Wildlife bird's resilience is strengthened by alternative habitats, high mobility, immigration, and adaptability. Maintaining landscape heterogeneity and native vegetation (mangroves) provides habitats that serve as a refuge for wildlife and facilitate their resilience. Birds of prey can be resilient to hurricanes due to their high mobility between different habitats (Martínez-Ruiz \& Renton, 2018). Bird immigration and its adaptability to the relative frequency of hurricanes are resilience factors for repopulating impacted environments (Johnson \& Winker, 2010).

\section{Water availability}

Angelina Martínez-Yrízar et al. (2018) state that an ecosystem's resilience of dry tropical forests to extreme hydrometeorological events seems to be strongly linked to water availability after the hurricane. Water is the key to ecosystem processes, especially in dry tropical forest biomes, where spatial and temporal variance in liquid availability is high. On the other hand, water availability through artificial floods also influences forest regeneration of small plants after the destruction caused by hurricanes (Vogt et al., 2012).

\section{Soil}

Two soil factors that promote ecological resilience were found. Gavito et al. (2018) revealed that nutrient availability, leaf litter quality, and decomposition were resilient to hurricane due to the diversity and heterogeneity of tree cover in the region. According to Walters and Kirwan (2016), resilience to sea-level rise in coastal ecosystems, such as swamps and barrier islands, is benefited by sediment deposition (1.96 to 5.9 in) during low-intensity storms by increasing the elevation of the ground and vegetation productivity. On the other hand, they also highlight that a greater increase in sediment accumulation can reduce growth and increase mortality of swamp vegetation, which paradoxically can lead to a decrease in resilience. 


\section{Infrastructure}

The articles reviewed highlight the recovery capacity importance of electricity, water, and supply distribution networks to reduce the interruption of vital resources for the population damaged by hurricanes. The restoration of electrical energy is a priority factor, and for that reason, it is identified as the main element on which the operation of other systems depends. The speed at which it recovers will directly affect the repair of hospitals, water treatment plants, and other public services. The ability to build distribution networks to maintain the flow of food, water, fuel, and other elements necessary to meet the immediate population's basic needs is another key element to consider to strengthen resilience. Some aspects that favor resilience of infrastructures are synthesized in factors aimed at strengthening the system's capacity of resistance to the event, and the recovery ability to restore the system once it is broken (Table 7).

\section{Resistance capacity}

Resistance is the predictive and preventive planning phase in resilience processes and aims to withstand hurricanes' impact, focusing on the physical resistance of infrastructures with technological or engineering solutions. The resistance capacity is increased by the development of predictive strategies. Predictive planning and optimal equipment placement are effective actions to reduce time and cost in infrastructure repair, including electricity distribution networks (Khomami \& Sepasian, 2018). In the same way, Stephanie Pilkington and Hussam Mahmoud (2017) indicate actions that contribute to maintaining the resistance of coastal communities to the spatial and temporal variations of the impacts of hurricanes: (a) a better quality of physical infrastructure, (b) the increase in knowledge and experience, (c) recognition of the occurrence of hurricanes, (d) respect for stricter building codes, and (e) better preparation of residents. They argue that natural defenses are more suitable for community protection than artificial solutions and that the increase of population in correspondence with an increase in infrastructure and wealth diminishes these natural protections and endangers more population.

Planning is key to anticipate and mitigate possible damage from hurricane impact. To improve the resilience of energy and water distribution networks, Javad Najafi et al. (2019) proposed a micro-grid plan, with three solutions: (1) hardening the power distribution network; (2) updating the size of energy storage (battery size) in micro-networks to restore loads and water pumps; and (3) improve water tank size in the distribution network 
Table 7 Infrastructure factors that promote resilience in hurricane-affected areas

\begin{tabular}{|c|c|c|}
\hline Category & Subcategory & Author \\
\hline \multirow{14}{*}{ Resistance } & Recognition of the occurrence of hurricanes & \multirow{5}{*}{$\begin{array}{l}\text { Pilkington and } \\
\text { Mahmoud (2017) }\end{array}$} \\
\hline & Building codes & \\
\hline & Better-prepared residents & \\
\hline & Quality of infrastructure & \\
\hline & Knowledge and experience & \\
\hline & Delimitation of exposed areas & $\begin{array}{l}\text { Tokgoz and } \\
\text { Gheorge (2013) }\end{array}$ \\
\hline & Stock reserve and bulk deliveries & $\begin{array}{l}\text { Brown and Dawson } \\
(2016)\end{array}$ \\
\hline & Incorporation of micro networks & \multirow{4}{*}{ Najafi et al. (2019) } \\
\hline & Hardening of lines in the energy network & \\
\hline & Energy storage & \\
\hline & Water storage & \\
\hline & $\begin{array}{l}\text { Decreased dependency between systems } \\
\text { Automation }\end{array}$ & Najafi et al. (2018) \\
\hline & Optimal placement of repair teams & Khomami and \\
\hline & Predictive planning & Sepasian (2018) \\
\hline \multirow{5}{*}{ Recovery } & Maintain the flow of vital supplies & $\begin{array}{l}\text { Brown and Dawson } \\
\text { (2016) }\end{array}$ \\
\hline & Increase and mobilization of resources & \multirow{3}{*}{$\begin{array}{l}\text { Ouyang and Dueñas } \\
\text { Osorio (2014) }\end{array}$} \\
\hline & Repair of substations and transmission lines & \\
\hline & Repair of local distribution circuits & \\
\hline & Placement of generators & Najafi et al. (2018) \\
\hline \multirow{5}{*}{ Redundancy } & Minimize the use of just-in-time supply chains & \multirow{5}{*}{$\begin{array}{l}\text { Brown and Dawson } \\
(2016)\end{array}$} \\
\hline & Avoid spatial grouping of industries & \\
\hline & Diversify suppliers and supply routes & \\
\hline & Protection of industries with greater connectivity & \\
\hline & Stock reserves (vital supplies) & \\
\hline
\end{tabular}

Source: Authors, based on the authors mentioned in the table 
to reduce dependence on the operation of the energy distribution network. Infrastructures such as water distribution networks are interrupted due to its dependence on the power grid; this situation causes cities or regions to experience critical conditions, so it is suggested to quickly restore the service of the distribution system and decrease the dependence of the water network on electricity. The same authors add that the partial or total automation of energy distribution improves resilience.

Resilience calculation can be used to evaluate and compare mitigation and preparedness strategies to better organize response and recovery actions. Delimitation of exposed areas through the use of color representation of resilience of different types of buildings against different hurricane intensities is a factor that helps strengthen them (Tokgoz \& Gheorghe, 2013). Another problem that occurs after the impact of a hurricane is the interruption of distribution networks of supplies such as water and food. To improve this situation, Shaun Brown and Richard Dawson (2016) presented strategies to avoid the collapse caused by floods; among them, they indicate that reserves and bulk delivery can increase the resilience of the system and delay the impacts of any interruption.

\section{Recovery capacity}

At the moment of impact, resilience is understood as the ability to resist shock; if the system does not resist, resilience depends on the resilience of strategic functions to return to normal (Reghezza-Zitt, 2013). Aspects that promote resilience are linked, on the one hand, to the implementation of strategies to maintain the flow of vital supplies, such as food, water, fuels, and other resources before, during, and after a hurricane (Brown \& Dawson, 2016); and on the other hand, to the increase and mobilization of resources, restoration sequence, repair of local distribution circuits, and placement of electric power generators.

Hurricanes can simultaneously cause extensive failures in power systems components and lead to cascade failures in other services; this is indicated by Min Ouyang and Leonardo Dueñas-Osorio (2014), and they say that measures to improve the resilience of the electric power system and reduce economic losses strictly obey three factors. The first one deals with increasing and mobilizing restoration resources for repair teams, including crew, vehicles, equipment, and replacement components. The second one refers to the restoration sequence by priority: transmission substations; transmission lines; and vital facilities for public safety, health, and well-being, such as hospitals, water treatment plants, and public services. The third one consists of repairing local distribution circuits and delivering power from distribution nodes to individual users; the greater 
the number of users served by a local distribution circuit, the higher the repair priority should be. Another action consists in placing electric power generators of different capacities to meet the population immediate needs (Najafi et al., 2018).

\section{Redundancy}

Another important aspect that strengthens resilience is the ability to take advantage of previous experiences. Redundancy implies the development of resource management strategies to minimize the use of just-in-time supply chains; avoid spatial grouping of industry; diversify providers and routes; increase investment in the protection of industries with greater connectivity to the broader network of resources; have supply reserves, both locally and regionally; and increase the capacity to handle bulk deliveries of vital supplies (Brown \& Dawson, 2016).

\section{Mental health}

Mental health is one of the most explored fields of knowledge in hurricane resilience research; this factor highlights the elements that help the recovery of individuals due to trauma suffered by the effects of a hurricane. Factors that promote resilience (Table 8) are associated with social support (Harville et al., 2010), which is obtained through favorable living arrangements such as being married, cohabiting with someone or being parents, and having employment or have high socioeconomic status (Gruebner et al., 2015). Previous experience of people who have been exposed more

Table 8 - Mental health factors that promote resilience in hurricane-affected areas.

\begin{tabular}{|c|c|c|}
\hline Category & Subcategory & Author \\
\hline \multirow{5}{*}{ Social support } & Favorable life arrangements & \multirow{5}{*}{$\begin{array}{l}\text { Harville et al. (2010) } \\
\text { Gruebner et al. } \\
(2015)\end{array}$} \\
\hline & Being married or cohabiting with someone & \\
\hline & Be parents & \\
\hline & Have a job & \\
\hline & Have high socioeconomic status & \\
\hline Experience & Previous experience & Pietrzak et al. (2012) \\
\hline \multirow{2}{*}{ Financing } & For home repair & \multirow{2}{*}{ Lowe et al. (2015) } \\
\hline & For the restoration of water, energy services & \\
\hline
\end{tabular}

Source: Authors, based on the authors mentioned in the table 
frequently to hurricane effects enables them to be better prepared to face major disasters, and long term, they become more resilient to mental health difficulties (Pietrzak et al., 2012).

Some actions that promote mental health are the existence of financing through federal funds for housing recovery, infrastructure repair for rapid restoration of energy, water, and other immediate needs of the population, and investment in resilience measures to withstand future natural disasters (Lowe et al., 2015).

\section{Social}

Traditionally, hurricane resilience studies have focused on technical, physical, or material aspects, however, the capacity for social reaction plays a key role in the system's recovery. In the social component, the population's ability to organize to actively participate in decision-making fosters resilience. Social cohesion, culture, and communication are aspects indicated as keys to the organization. Planning and designing social resilience programs should take advantage of local knowledge, learning from previous experiences, and scientific research (Table 9).

\section{Social organization}

Community social organization can be a key aspect of resilience; its efficiency is strengthened by the presence of solid and historical roots of residents. If they live in the same neighborhood and believe in the same religion, the creation of social ties and relationships is facilitated. The recovery capacity is increased due to community ties and cohesion, culture adaptation, and communication to inform social aspects such as risk awareness of risk, social bond, and community culture (Leroy et al., 2016).

\section{Reorganization}

Reorganization capacity after a hurricane allows recovering normality and creates opportunities for the empowerment of vulnerable groups by restructuring networks of small groups with little representation to become community organizations (Overton, 2014).

\section{Human mobility}

Mobility data of individuals before, during, and after a hurricane help predict patterns that improve response capacity through the development 
of evacuation strategies (Wang \& Taylor, 2014), revealing an important correlation between the center of mass and radius of gyration of each movement during states of disturbance and stability. Data collected in stable states can help predict disturbance states and human mobility patterns during extreme events and develop strategies to improve evacuation actions and response speed, minimizing human suffering, economic damage, and loss of life.

\section{Planification}

Reducing vulnerability and increasing resilience has become a focus of research in disaster planning and in the creation of public policies. The participation of all stakeholders is essential in planning processes. Five aspects that favorably affect hurricane resilience have been identified: (1) coordination indicates that master planning is a way to ensure that individual strategies complement each other and progress toward coordinated resilience; (2) inclusion is about incorporating stakeholders in resilience planning; (3) diversity implies that research and academic organizations serve as neutral facilitators, allowing a diversity of actors to freely share information and plan for results with mutual benefits; (4) responsibility stipulates that leadership helps to build resilience; and (5) commitment benefits efforts for resilience planning (Becker et al., 2015).

\section{Programs design}

Programs design refers to factors that must be considered in the design of hurricane recovery planning programs. Five factors were identified in this group: (1) vulnerability profile underlines the importance of developing an updated profile of vulnerable population, and that it be integrated into emergency management or recovery plans, with special consideration to socially marginalized groups; (2) social research consists of rethinking and clarifying the objectives of the register of vulnerable populations, based on research in social sciences to find out how vulnerable groups self-identify; (3) local knowledge points out the importance of creating and promoting opportunities for community members to share local knowledge and past experiences, highlighting innovative solutions; (4) distribution of risks and benefits enhance the need to review existing programs to determine the spatial and temporal distribution of risks and benefits of policies or programs among the population; and (5) experience shows that people's memories and experiences contribute to the preparation of predictable disasters (Torres \& Alsharif, 2016). 
Table 9 - Social factors that promote resilience in hurricane-affected areas

\begin{tabular}{lll}
\hline Category & Subcategory & Author \\
\hline Organization & Solid and historical roots & \\
Links & Community social links & Leroy et al. (2016) \\
Cohesion & Community cohesion & \\
Culture & Adaptive culture & Overton (2014) \\
\hline Reorganization & Network restructuring & Wang and Taylor (2014) \\
\hline Mobility & Evacuation strategies & \\
\hline & Coordination & Becker et al. (2015) \\
& Inclusion & \\
Planning & Diversity & \\
& Responsibility & \\
& Commitment & Torres and Alsharif (2016) \\
\hline Program design & Local knowledge & \\
& Social investigation & \\
\hline Indicator system & Monitoring & \\
\hline
\end{tabular}

Source: Authors, based on the authors mentioned in the table

\section{Indicator system}

Oscar Frausto et al. (2016) developed a system of urban resilience indicators for coastal cities in the Mexican Caribbean. They point out that the system represents a novel tool in climate change and resilience studies. This system allows for monitoring the progress of the community's well-being. It consists of four categories: (1) living conditions of individuals, groups, society, or community; (2) history of adverse events and behavior and learning experiences in response to these events; (3) the destruction and negative impact of main dangers; and (4) the actions taken to face adversities.

\section{Conclusions}

Resilience studies require a radical change, moving from a technical paradigm to a systemic one that includes a social focus on issues such as sol- 
idarity and human development, linked to the isolation, inequality, social segregation, and fragmentation of most urban areas.

The multidisciplinary nature of the resilience approach, and the diversity of theoretical approaches have made it difficult to develop a transversal definition. Therefore, a consensus between different fields of study and theoretical approaches has not been possible. The persistence of the traditional approach focused on increasing resistance by building physical infrastructure to avoid danger is recognized.

The paradigm shift toward the inclusion of a social approach begins to be glimpsed. The studies reviewed here present conceptualizations, strategies, actions, and recommendations focalized on specific objects. Finally, no comprehensive or holistic model includes the most socialized components of the system (economic, social, institutional, infrastructure, ecological).

The content analysis allowed the identification and categorization of the information obtained in four groups of factors: ecological, social, infrastructure, and mental health, evidencing the close relationship between the elements of the system to achieve its rapid recovery from the disaster caused by a hurricane. The study reinforces current research on the operation of resilience through different spatial and temporal scales, reflecting the factors that promote the resistance and recovery capacity of the system in the face of the negative effects caused by hurricanes. The analysis of the concept development allows defining resilience as the capacity of the system to resist, recover, and transform in face of a disturbance, and emerge stronger to face future adversities. The lack of clarity of the concept of resilience in the literature leads to a critical analysis and identify what remains to be done in the future.

The commitment of scientific research focused on resilience is to create consensus for its conceptualization and operationalization to facilitate its transition to practice. Studies are fragmented, even within the same field of study. Future research should analyze hurricane resilience as a complex, dynamic, and circular system that includes all the elements that interact in the recovery process.

The literature review contributed to concentrating dispersed and fragmented information in a single document, allowing an overview of the approach to hurricane resilience among different areas of knowledge. The classification by categories made it possible to recognize the factors that promote resilience in the different components from a systemic approach.

The need for qualitative studies, based on social research, that integrate the knowledge of the population for planning and decision-making is emphasized. In this sense, it is a priority to determine strategies and take on the recommendations to strengthen disaster recovery capacity. There is a need for a holistic approach that leads appropriate actions to 
avoid economic and social crises, but especially the loss of human lives. The factors that promote resilience to the hurricanes identified in this review present a broad view of the subject and also provide signals that can help develop programs to increase resilience and decrease the damage caused by these phenomena.

While the results of literature review do not show a global scenario of resilience to hydrometeorological phenomena, they do recognize a group of factors that promote resilience to the damage caused by the impact of hurricanes.

The literature review was based on all open access articles available up to 2019 on the Science Direct and Scopus search engines. Restricted access articles were not considered, only articles that contained the words "resilience" and "hurricanes" in the title.

Due to the small number of articles published under the search criteria used in both databases, all were included in the content analysis; as a result, the selection made it possible to classify and group the data by areas of knowledge and by components of resilience. For future research, it will be necessary to expand and diversify the literature with search criteria other than the word "hurricanes" and include terms associated with hydrometeorological phenomena such as "typhoons," "tropical storms," and "cyclones." It will also be necessary to include critical views on the use of the concept of resilience, especially from social sciences.

\section{ACKNOWLEDGMENTS}

This study is part of a PhD in environmental sciences at the Center of Regional Development Sciences of the Autonomous University of Guerrero, Mexico, registered in the National Program of Quality Graduate Studies. The development of this work was possible thanks to the support provided by the National Scholarships program of the National Council of Science and Technology of the Mexican government, with scholarship number 589495, and by the mixed scholarship carried out in the Laboratory of Space Observation and Research Division of Sustainable Development, University of Quintana Roo, Mexico. This article follows from the doctoral thesis "Factors that strengthen resilience to hurricanes in coastal areas."

ADOLFO LUCERO ÁLVAREZ, PhD student in environmental sciences at the Center of Regional Development Sciences of the Autonomous University of Guerrero, Mexico, on "Hurricane Resilience Research Zone." He holds a master's degree in sustainable tourism management sciences from the Autonomous University of Guerrero; his studies were carried out in the period 2014-2016, with a line of research in tourist carrying capacity. He has a bachelor's degree in tourism from the Academic Unit of Tourism in the 1986-1993 generation from the same university. Email: 1llucerooo@hotmail.com 
COLUMBA RODRÍGUEZ ALVISO. Professor-researcher at the doctorate in environmental sciences of the Autonomous University of Guerrero. She holds a PhD in geography (UNAM). She leads the Academic Body "Educational Innovation and Sustainability" (consolidated), and works on the topics "Environmental Education for Sustainability and Environmental Geography." She has directed and/or advised thesis in doctorate, master's, and bachelor's degrees. She has taken academic stays at universities in Mexico, Colombia, and Spain. She has participated in 23 articles, 4 book chapters, and national and international conferences in Mexico, Spain, Colombia, and Ecuador. Email: columbaalviso@uagro.mx

OSCAR FRAUSTO MARTÍNEZ. Full-time professor at the University of Quintana Roo; he holds a bachelor's and master's degree in geography from the UNAM, Mexico, and a PhD in engineering from Bauhaus University, Germany. He is a member of the National System of Researchers and a full member of the Mexican Society of Geography and Statistics. He is responsible for the International Chair in Integrated Management of the Stephen Olsen Coastal Zone and member of the Academic Technical Committee of the Network for Hydrometeorological Disasters and Climate Change-REDESClim of Conacyt. His research area is the geography of risk and the territorial indicators of sustainable development. Email: ofrausto@uqroo.edu.mx

JOSÉ LUIS APARICIO LÓPEZ. PhD in environmental sciences and professor-researcher at the doctorate in environmental sciences of the Autonomous University of Guerrero. He is a member of the Academic Body "Educational Innovation and Sustainability" (consolidated), and cultivates the lines of research "Educational Innovation, Education for Sustainability and mainstreaming environmental education into the curricula." He is a member of the Institutional Commission for Educational Development of the UAGro. He has directed and/or advised thesis in doctorate, master's, and bachelor's degrees. He has taken academic stays in Colombia, Mexico, and Spain. He has authored and co-authored several articles, highlighting ten in JCR and Conacyt catalogs. He also has written two book chapters and three books. Email: joselopez@uagro.mx

ALEJANDRO DÍAZ GARAY completed his undergraduate studies in economics at the Metropolitan Autonomous University, holds a master's degree in social sciences from the Autonomous University of Guerrero, and a doctorate in geography from the National Autonomous University of Mexico, where he passed his doctoral dissertation with merit. He is a professor with 29 years of experience in the field of social sciences and a specialist in international migration and sustainable tourism development. He has written 8 scientific articles, coordinated 13 books, and authored 24 book chapters in book publishers with recognized international prestige. Technical manager of research projects with external funding, and member of the Academic Technical Council of the Ibero-American Thematic Network of Research Academies on Migration and Development of Conacyt, as well as of the National System of Researchers, level 1. Email: adiazgaray@gmail.com 
MAXIMINO REYES UMAÑA is attached to the doctorate in environmental sciences at the Center of Regional Development Sciences of the Autonomous University of Guerrero. He participates in the projects "Environmental Quality and Sustainable Development (Indicators) 2014" (financed by PROMEP) and "Estimation of Carbon Sequestration in the Temperate Forest of the Hueyapa river micro-basin, Guerrero, Mexico," (SEMARNAT CALL- CONACYT -2016-01-278639). He has a distinction as PROMEP Profile 2019; he is a member of the consolidated Academic Body UAGro-CA-29, a member of the academic sector of the basin council of the coast of Guerrero, a member of the state registry of researchers of COCYTIEG, and a member of the Environmental Quality Network (PROMEP). Email: maxis_99@ hotmail.com

\section{REFERENCES}

Alexander, D. (2006). Globalization of disaster: trends, problems and dilemmas. Journal of International Affairs 59(2): 1-22.

Becker, A. H., Matson, P., Fischer, M., \& Mastrandrea, M. D. (2015). Towards seaport resilience for climate change adaptation: Stakeholder perceptions of hurricane impacts in Gulfport (MS) and Providence (RI). Journal of Progress in Planning 99: 1-49.

Brown, S., \& Dawson, R. (2016). Building network-level resilience to resource disruption from flooding: Case studies from the Shetland Islands and Hurricane Sandy. E3S Web of Conferences (Vol. 7, p. 04008). EDP Sciences.

Cutter, S. L., Barnes, L., Berry, M., Burton, C., Evans, E., Tate, E., \& Webb, J. (2008). A place-based model for understanding community resilience to natural disasters. Global environmental change 18(4): 598-606.

Frausto, O., Vázquez, A., Arroyo, L., Castillo, L., \& Hernández, M. (2016). Hurricane resilience indicators in Mexican Caribbean coastal cities. International Journal of Safety and Security Engineering 6(4): 755-763.

Fuller, S. (2013). Book review: Antifragile: how to live in a world we don't understand. LSE Review of Books.

Gavito, M. E., Sandoval-Pérez, A. L., del Castillo, K., Cohen-Salgado, D., Colarte-Avilés, M. E., Mora, F., .. . \& Urquijo-Ramos, C. (2018). Resilience of soil nutrient availability and organic matter decomposition to hurricane impact in a tropical dry forest ecosystem. Forest Ecology and Management 426: 81-90.

Gruebner, O., Lowe, S. R., Sampson, L., \& Galea, S. (2015). The geography of post-disaster mental health: Spatial patterning of psychological vulnerability and resilience factors in New York City after Hurricane Sandy. International journal of health geographics 14(1): 16.

Harville, E. W., Xiong, X., Buekens, P., Pridjian, G., \& Elkind-Hirsch, K. (2010). Resilience after Hurricane Katrina among pregnant and postpartum women. Women's health issues 20(1): 20-27.

Holt, R. D. (2006). Making a virtue out of a necessity: Hurricanes and the resilience of community organization. Proceedings of the National Academy of Sciences 103(7): 2005-2006. 
Johnson, A. B. \& Winker, K. (2010). Short-term hurricane impacts on a neotropical community of marked birds and implications for early-stage community resilience. PLoS One 5(11).

Khomami, M. S., \& Sepasian, M. S. (2018). Pre-hurricane optimal placement model of repair teams to improve distribution network resilience. Electric Power Systems Research 165: 1-8.

Leroy, J., Amdal, J., Vuillet, M., Cariolet, J. M., Diab, Y., \& Becue, V. (2016). Vulnerability and social resilience: Comparison of two neighborhoods in New Orleans after Hurricane Katrina. In E3S Web of Conferences (Vol. 7, p. 08002). EDP Sciences.

Lowe, S.R., Sampson, L., Gruebner, O., \& Galea, S. (2015). Psychological resilience after Hurricane Sandy: The influence of individual-and community-level factors on mental health after a large-scale natural disaster. PloS one 10(5).

Maguire, B., \& Hagan, P. (2007). Disasters and communities: understanding social resilience. Australian Journal of Emergency Management 22(2): 16.

Martínez-Ruiz, M., \& Renton, K. (2018). Habitat heterogeneity facilitates resilience of diurnal raptor communities to hurricane disturbance. Forest Ecology and Management 426: 134-144.

Martínez-Yrízar, A., Jaramillo, V. J., Maass, M., Búrquez, A., Parker, G., ÁlvarezYépiz, J. C., . . \& \& Sarukhán, J. (2018). Resilience of tropical dry forest productivity to two hurricanes of different intensity in western Mexico. Forest Ecology and Management 426: 53-60.

Najafi, J., Peiravi, A., Anvari-Moghaddam, A., \& Guerrero, J. M. (2019). Resilience improvement planning of power-water distribution systems with multiple microgrids against hurricanes using clean strategies. Journal of Cleaner Production 223: 109-126.

Najafi, J., Peiravi, A., \& Guerrero, J. M. (2018). Power distribution system improvement planning under hurricanes based on a new resilience index. Sustainable cities and society 39: 592-604.

Ouyang, M., \& Dueñas-Osorio, L. (2014). Multi-dimensional hurricane resilience assessment of electric power systems. Structural Safety 48: 15-24.

Overton, L. R-A. (2014). From vulnerability to resilience: An exploration of gender performance art and how it has enabled young women's empowerment in post-hurricane New Orleans. Procedia Economics and Finance 18: 214-221.

Paz, H., Vega-Ramos, F., \& Arreola-Villa, F. (2018). Understanding hurricane resistance and resilience in tropical dry forest trees: A functional traits approach. Forest Ecology and Management 426: 115-122.

Pietrzak, R. H., Tracy, M., Galea, S., Kilpatrick, D. G., Ruggiero, K. J., Hamblen, J. L., \& Norris, F. H. (2012). Resilience in the face of disaster: Prevalence and longitudinal course of mental disorders following Hurricane Ike. PLoS One 7(6).

Pilkington, S. \& Mahmoud, H. (2017). Spatial and temporal variations in resilience to tropical cyclones along the United States coastline as determined by the multi-hazard hurricane impact level model. Palgrave Communications 3(1): 14.

Pineda, O. K., Kim, H., \& Gershenson, C. (2019). A novel antifragility measure based on satisfaction and its application to random and biological Boolean networks. Complexity 2019. 
Quenault, B. (2013). Retour critique sur la mobilization du concept de résilience in lien avec l'adaptation des systèmes urbains au changement climatique. EchoGéo (24).

Reghezza-Zitt, M. (2013). Utiliser la polysémie de la résilience pour comprendre les différentes approches du risque et leur possible articulation. EchoGéo (24).

Rota, F. S., Bagliani, M., \& Feletig, P. (2020). Breaking the black-box of regional resilience: A taxonomy using a dynamic cumulative shift-Share occupational approach. Sustainability 12(21): 9070.

Taquechel, E. F., \& Lewis, T. G. (2017). A right-brained approach to critical infrastructure protection theory in support of strategy and education: deterrence, networks, resilience, and "antifragility." Homeland Security Affairs 13(34).

Tokgoz, B. E., \& Gheorghe, A.V. (2013). Resilience quantification and its application to a residential building subject to hurricane winds. International Journal of Disaster Risk Science 4(3): 105-114.

Torres, H., \& Alsharif, K. (2016). Reflecting on resilience in Broward County, Florida: A newspaper content analysis about Hurricane Wilma recovery. International Journal of Disaster Risk Reduction 19: 36-46.

United Nations. (2015). Transforming our world: The 2030 Agenda for Sustainable Development. https://unctad.org/meetings/es/SessionalDocuments/ ares70d1_es.pdf.

Vogt, J., Skóra, A., Feller, I. C., Piou, C., Coldren, G., \& Berger, U. (2012). Investigating the role of impoundment and forest structure on the resistance and resilience of mangrove forests to hurricanes. Aquatic botany 97(1): 24-29.

Walters, D. C., \& Kirwan, M. L. (2016). Optimal hurricane overwash thickness for maximizing marsh resilience to sea level rise. Ecology and Evolution 6(9): 2948-2956.

Wang, Q. \& Taylor, J. E. (2014). Quantifying human mobility perturbation and resilience in Hurricane Sandy. PLoS one 9(11).

\section{Reconocimiento de factores que promueven la resiliencia ante huracanes}

Adolfo Lucero Álvarez, Columba Rodríguez-Alviso, Oscar Frausto Martínez, José Luis Aparicio López, Alejandro Díaz Garay, Maximino Reyes Umaña

Resumen: La investigación científica sobre resiliencia ha incrementado paralelamente a los daños económicos y casualidades humanas generadas por el paso de huracanes. El objetivo de esta investigación es identificar los factores que promueven la resiliencia en áreas impactadas por huracanes, mediante la revisión de literatura especializada. El estudio es cualitativo basado en análisis de contenido de publicaciones científicas en diferentes campos de estudio. En específico, se revisaron veintisiete artículos publicados entre 2006 y 2019. La resiliencia es multidisciplinar y hay una coincidencia al definirla: la capacidad de un sistema para absorber, resistir y recuperarse de los desastres. Predomina un enfoque de in- 
fraestructura física, pero comienza a distinguirse uno social. Los factores que promueven la resiliencia se agrupan en cuatro categorías: ecológica, social, infraestructura y salud mental.

Palabras clave: desastre, disturbio, recuperación, resistencia, riesgo, sistema socioecológico

\section{La reconnaissance des facteurs favorisant la résilience face aux ouragans}

Adolfo Lucero Álvarez, Columba Rodríguez Alviso, Oscar Frausto-Martínez, José Luis Aparicio López, AlejandroDíaz Garay, Maximino Reyes Umaña

Résumé: Les pertes en vies humaines et les dégâts économiques causés par les ouragans ont motivé la recherche scientifique sur la résilience, définie comme la capacité d'un système à absorber, à résister et à se remettre des catastrophes. Les écrits publiés sont dispersés et fragmentés dans différents domaines d'étude. L'objectif de cette recherche était d'identifier les facteurs favorisant la résilience dans des zones touchées par les ouragans en examinant la littérature spécialisée. L'étude est qualitative, basée sur une analyse de contenu. Vingt-sept articles publiés entre 2006 et 2009 ont été examinés. L'approche en termes d'infrastructure physique prédomine, mais une approche sociale commence à se distinguer. Les facteurs favorisant la résilience peuvent être regroupés en quatre catégories : écologique, sociale, infrastructurelle et celle de la santé mentale.

Mots-clés: catastrophe, ouragans, récupération, résilience, résistance, risque, système socio-écologique 